\title{
THEORETICAL FRAME FOR TESTING CRITICAL TRANSPORT INFRASTRUCTURE ELEMENTS
}

\author{
Eva SVENTEKOVA ${ }^{1}$, Zdenek DVORAK ${ }^{2}$ \\ ${ }^{1}$ Faculty of Special Engineering, University of Zilina, 01026 Zilina, Ul. 1.maja 32, Slovak Republic \\ E-mail: Eva.Sventekova@fsi.uniza.sk \\ ${ }^{2}$ Faculty of Special Engineering, University of Zilina, 01026 Zilina, Ul. 1.maja 32, Slovak Republic
}

Accepted 13 November, 2012

\begin{abstract}
The authors in the paper deal with the role of road transport in terms of critical infrastructure and they also deal with criteria established to ensure the required level of connection of critical infrastructure elements by road transport. The attention is paid to the influence of constraints on the quality of traffic flow as permissible traffic intensity, the influence of the proportion of heavy vehicles, reserve capacity, waiting time. The contribution deals with transport and technical management of highway segments.
\end{abstract}

Keywords: critical infrastructure, permissible traffic intensity, transport management

\section{INTRODUCTION - CRITICAL INFRASTRUCTURE}

Protecting critical infrastructure is essential for internal security and safety of other European Union Member States. Disruption or destruction of critical infrastructure, or part of the elements can result in fatalities, serious damage to human health, property damage, environmental degradation and long-term disruption of public confidence in public authorities and other legal entities.

Critical infrastructure is that part of the national infrastructure (selected organizations and institutions, structures, equipment, services and systems), in which the destruction or disablement as a result of risk factors may cause danger or disruption of political and economic operation of state or threat to life and health. The critical infrastructure parts are also objects of defense infrastructure. (Lovecek and Reitspis, 2011)

An element of critical infrastructure is such an element of national infrastructure, which has been designated as an element of critical infrastructure, as the destruction or disruption due primarily to a terrorist attack can affect any area of national security, for example:

- the political operation of the state including the functioning of public administration,

- defense,
- operation of the economy of the state,

- life, health or property of the population,

- transportation, information and communication systems,

- environment.

The criteria for determining critical infrastructure elements are:

- unacceptable risk unique element,

- a potential target of terrorist attack,

- the generalization,

- an exclusivity, (Novak, 2011).

\section{CRITICAL TRANSPORT INFRASTRUCTURE IN THE SLOVAK REPUBLIC}

The Slovak Republic maintains approximately 18 thousand kilometres of streets, roads and highways, over 7800 road bridges and over 2280 rail bridges, $3500 \mathrm{~km}$ of railroads, 13 public airports and 14 private airports. While each of these facilities provides much-needed travel and economic links to local communities, the vast majority supports primarily local movements of persons and goods. Only a small subset of the entire transportation infrastructure can be considered of major national interest. (Sekcia cestnej dopravy MD SR, 2011) 
Although no universally agreed upon definition or criteria for the critical transport infrastructure (CTI) most observers would agree that the CTI is composed of those transportation facilities whose removal from service would significantly affect public safety, national security, economic activity or environmental quality. Some experts suggest that only those facilities that are essential to national defence or global economic activity should be designated as "critical."

Any facility falling short of these measures can be labelled "important". In the absence of a formal CTI designator, federal, state and local officials have the latitude to designate CTI facilities of varying degrees of importance. That is, what is deemed critical to a particular state or city may not be critical from a national perspective and vice versa. A related but distinct concept involves "transportation lifelines," transportation facilities providing essential accesses for emergency services to disaster sites and allowing for the evacuation of at-risk persons and property from those sites. Transportation lifelines are primarily local in nature and are defined by the location, type, and severity of the disaster and by the demographics and land use of the region in which the disaster occurs. Again, designated local and regional lifelines may not coincide with national ones. (Simak and Ristvej, 2009)

Critical infrastructure elements in road transport are ways of I. class and the bridges on them as well. Their disruption or destruction would affect the planned transfers forces, as well as supply and transportation during the war. National Highway Company, Ltd. managed and maintained operating highways, roads for motor vehicles and first class roads in the area of roads. It is also an investor, which provides for the construction of highways. As elements of critical infrastructure may be under the motorway and road network selected some road tunnels and bridges and cable network. These objects in the protection of critical infrastructure elements in the sub-sector of road transportation require a specific approach involved is often part of the black spots.

The tunnels would need to increase repression prevent shipments of dangerous goods because the signs are excluded, but unfortunately not respected. The fact could lead to incidents during normal transport and possibly be used for preparing a terrorist attack.
In terms of peace is hard to identify objects and roads covered by the Slovak Road Administration, that would be included in critical infrastructure and their removal should a major impact on activities of the organization. Evidence of this, there is relatively common serious accident, which rejected a way of operation, to prevent passage, or it partially difficult. In a relatively short time adopted the solution by diverting traffic to other communication. (Sventekova, 2011)

Functional level of road transport needs CTI determine:

- the desired running speed,

- achievable travel speed,

- composition of traffic flow,

- maneuvering options

- wideness category of communication

- horizontal and vertical line of communication.

The role of road transport in critical transport infrastructure is:

- to maintain safe and accessible way,

- to operate and maintain traffic flows on the move

- to provide active support to the driver and provide travel information and services.

For the proper functioning of road infrastructure all residents are in need every day. In the future, defined critical infrastructure in road transport will be very important for the state. Disruption of element of critical transport infrastructure has a negative impact on the functioning of the transport system. These consequences are more severe, more complex infrastructure system is disturbed. It is necessary to eliminate or at least mitigate the impact of potential risks. It is necessary to analyze risks, weaknesses and level of their own capacity. It is necessary to establish and consolidate minimum standards for protection of critical infrastructures, reduce vulnerability, to protect people and critical resources and systems on which depends the existence of society at the national level to harmonize rules for transporting hazardous substances, put great emphasis on a key transport points such as bridges, tunnels, intersections, or equipment designed to load or unload goods. (Vidrikova, 2011)

\section{THEORETICAL BASES IN PERFORMANCE TESTING OF HIGHWAY SECTION}

To calculate the performance of highway sections is necessary to know the traffic load of each 
direction and the percentage of heavy vehicles. Both directions of the highway section are addressed separately.

Some quantities affect the traffic and thereby achievable rate and capacity of the highway section.

The slope of the highway has a significant impact on traffic flow. The routes, which are kept in a steep (more than $2 \%$ ) partially reduces the speed of heavy vehicles, which in turn affects the speed of passenger cars. Traffic flow analysis shows significant differences depending on the function and position of highway section. The impact of heavy vehicles on the quality of traffic flow is expressed as a percentage of total heavy vehicle traffic flow and the calculation of capacity and permeability must be taken into account.

Incident may adversely affect the capacity of highway sections, included among the elements of critical infrastructure. Capacity of the highway sections with speed limits is given in table. 1 .

Table 1: Capacity of the highway sections with speed limits

\begin{tabular}{|c|c|c|c|c|}
\hline \multirow{3}{*}{ Number of lanes } & \multirow{3}{*}{ Speed limits } & \multicolumn{3}{|c|}{ Capacity (vehicles/hour) } \\
\cline { 3 - 5 } & & $\mathbf{0 \%}$ & $\mathbf{1 0 \%}$ & $\mathbf{2 0 \%}$ \\
\cline { 3 - 5 } & 120 & 5700 & 5400 & 5100 \\
\hline \multirow{2}{*}{3} & $100 / 80 /$ tunnel & 5800 & 5500 & 5200 \\
\cline { 2 - 5 } & 120 & 4000 & 3800 & 3600 \\
\hline \multirow{2}{*}{$\mathbf{2}$} & $100 / 80 /$ tunnel & 4100 & 3900 & 3700 \\
\hline $\mathbf{2}$ & Work on the road & - & 3300 & - \\
\hline
\end{tabular}

Crucial in assessing the performance of the highway section as an element of critical transport infrastructure may have a slope of highway section.

Table 2 shows the allowable values of traffic intensity for the agglomeration of the highway with speed restrictions in force on the plane, for fall and for max. $2 \%$ slope for percentage of heavy vehicles $10 \%$.
For resolution of traffic flows grades from $\mathrm{A}$ to $\mathrm{F}$ is valid the tolerance between the degree of saturation according to Table 3 .

The table 3 deals with the binding level of quality of traffic flow with a median duration of travel by car, with a mean travel speed, traffic density and degree of saturation for a 2 lanes highway on a flat route with no speed limits outside agglomerations.

Table 2: Permissible intensities at reduced speed

\begin{tabular}{|c|c|c|c|c|c|}
\hline \multirow{3}{*}{ Quality } & \multicolumn{4}{|c|}{ Permissible intensity of direction (vehicles/hour) } \\
\cline { 2 - 6 } & \multicolumn{3}{|c|}{ 3 lanes } & \multicolumn{3}{c|}{ 2 lanes } \\
\cline { 2 - 6 } & $\mathbf{1 2 0}$ & $\mathbf{1 0 0 / 8 0}+$ tunnel & $\mathbf{1 2 0}$ & $\mathbf{1 0 0 / 8 0}+$ tunnel & Work on the road \\
\hline A & 1620 & 1650 & 1140 & 1170 & 990 \\
\hline B & 2970 & 3025 & 2090 & 2145 & 1815 \\
\hline C & 4050 & 4125 & 2850 & 2925 & 2475 \\
\hline D & 4860 & 4950 & 3420 & 3510 & 2970 \\
\hline E & 5400 & 5500 & 3800 & 3900 & 3300 \\
\hline F & - & - & - & - & - \\
\hline
\end{tabular}

Table 3: Quality of traffic flow

\begin{tabular}{|c|c|c|c|c|}
\hline Quality & $\begin{array}{c}\text { median duration } \\
\text { of travel } \\
(\mathbf{m i n} / \mathbf{1 0 0 k m})\end{array}$ & $\begin{array}{c}\text { mean travel speed } \\
(\mathrm{km} / \mathrm{h})\end{array}$ & $\begin{array}{l}\text { traffic density } \\
\text { (vehicles/km) }\end{array}$ & $\begin{array}{c}\text { degree of } \\
\text { saturation } \\
(-)\end{array}$ \\
\hline $\mathbf{A}$ & $\leq 46$ & $\geq 130$ & $\leq 8$ & $\leq 0,30$ \\
\hline B & $\leq 48$ & $\geq 125$ & $\leq 16$ & $\leq 0,55$ \\
\hline $\mathrm{C}$ & $\leq 52$ & $\geq 115$ & $\leq 23$ & $\leq 0,75$ \\
\hline $\mathbf{D}$ & $\leq 60$ & $\geq 100$ & $\leq 32$ & $\leq 0,90$ \\
\hline $\mathbf{E}$ & $\leq 75$ & $\geq 80$ & $\leq 45$ & $\leq 1$ \\
\hline $\mathbf{F}$ & $>75$ & $<80$ & $>45$ & - \\
\hline
\end{tabular}

The quality grades mean:

- Degree A - The driver is very rarely affected by other drivers, the degree of saturation is very low, the driver does not have his speed limit in response to road permits, and the traffic flow is free. 
- Degree B - The minor influences from other drivers operate to driver, these effects are not serious, the degree of saturation is minimal, the speed can reach the desired level, and traffic flow is almost free.

- Degree C - The presence of other road users is felt, the individual freedom of movement is already restricted, the degree of saturation is approximately in the middle, speed is no longer entirely optional, and traffic flow is stable.

- Degree D - There is always the reciprocal influence of road users, leading to conflict and mutual constrains, the degree of saturation is high, the possibility of individual choice and speed lane is heavily restricted, traffic flow is still stable.

- Degree E - Cars are moving in columns, the degree of saturation is very high, small or shortterm increase in the intensities can cause traffic congestion, there is a danger of traffic flow collapse, traffic flow is changed from stable to unstable, flow capacity is filled.

- Degree F - The intensity of the incoming traffic exceeds capacity, transport collapses, there are congestions, which alternate with "stop and go" nature of traffic, and highway section is overloaded.

In the case of the inclusion of highway section between the elements of critical transport infrastructure is the task for responsible to maintain a minimum grade $\mathrm{C}$ in all situations. (Vidrikova and Boc, 2013)

\section{Procedure for performance testing}

For testing the performance of highway section as a potential element of critical transport infrastructure is recommended to follow the following procedure:

- to determine the required travel speed,

- to choice of cross-sectional,

- to set the lines and elevation maps,

- to define the desired level of quality,

- dimensioning and calculation of the current share of heavy traffic,

- to affect inventory quantities as longitudinal slope, number of lanes, section position, speed reduction.

\section{CONCLUSION}

Taking into account the density of road network, it is possible to conclude that in the Slovak Republic is in principle possible to set a diversionary routes for the remaining land communications. It seems that the transport processes will be provided but with a time delay, which should not harm the operation of the national economy.

Critical transport infrastructure should include only those transport systems, whose loss, damage or destruction could result in loss of human life, serious damage to human health, property damage, or deterioration environment. The measures used to protect transport infrastructure should reduce the possibility of failure and limit the effects of these failures.

\section{REFERENCES}

Lovecek, T., \& Reitspis, J. (2011). Projektovanie a hodnotenie systémov ochrany objektov. 1 . vyd. Žilina, Žilinská univerzita, ISBN 978-80-5540457-8.

Novak, L. (2011). Kritičeskaja infrastruktura transporta v Slovackoj respublike. In: Mechanics Transport Communications. ISSN 1312-3823. Iss. 3 (2011), X-149-X-155.

Sekcia cestnej dopravy MD SR (2011). Technické podmienky pozemných komunikácií, Bratislava.

Simak, L., \& Ristvej, J. (2009). The Present Status of Creating the Security System of the Slovak Republic after Entering the European Union, Journal of Homeland Security and Emergency Management, 6(1), ISSN 1547-7355.

Sventekova, E. (2011). Black spot management and critical infrastructure. In: Mechanics, Transport, Communications, 21-25, ISSN 1312-3823.

Vidrikova, D. (2011). Ochrana prvkov kritickej infraštruktúry v cestnej doprave. In: Logistický monitor, september 2011, ISSN 1336-5851.

Vidrikova, D. \& Boc, K. (2013) Ochrana kritickej infraštruktúry 1.čast', Žilina, Žilinská univerzita, ISBN 978-80-554-0654-1.

\section{AKNOWLEDGEMENT}

This work was supported by the Slovak Research and Development Agency under the contract No. APVV-0471-10. 